\title{
AVALANCHE HAZARD IN THE CAIRNGORM MOUNTAINS, SGOTLAND
}

\author{
By R. G. W. WARD \\ (Department of Geography, University of Aberdeen, Aberdeen ABg 2UF, Scotland)
}

\begin{abstract}
Avalanche accidents are increasing in Scotland and fatalities now average two each year. The victims are either mountaineers or cross-country skiers as the problem is confined to the steeper and remoter slopes. Studies in the Cairngorm Mountains have shown that Scottish snow differs from alpine snow in three respects: depeh hoar does not occur in Scotland, higher values are found for density and rammsonde penetration, and ice layers are more abundant. Slab avalanches are found on slopes of about $35^{\circ}$ and sluffs oz slopes of $30^{\circ}$ and steeper. Although most avalarches are small, crown fracture lines reach a maximum length of $500 \mathrm{~m}$, and slabs may be up to eight metres thick. Preliminary correlations between avalanche release and weativer conditions have shown the importance of cold periods following heavy snow falls and the significance of thaws. Much more needs to be done before an avalanche-forecasting service could be provided, not the least of which is persuading likely beneficiaries that such a service would be worthwhile.
\end{abstract}

Rúsumé. Risques d'autalanches dons les Caingorm Mountains, Ecosse. Les accidents d'avalanches augmentent en Ecosse et la moyenne des victimes est maintenant de deux par an. Les victimes sont soit des alpinistes ou des skieurs-randonneurs car le problème est limité aux pentes les plus fortes et les plus reculées. Les études dans les Cairngorm Mountains ont montré que la neige écossaise diffère de la neige alpine sur trois points : le givre

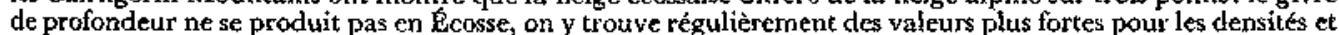
la pénétration des sondes de battage et les niveaux de glace sont plus abondants. Des avalanches de plaque sont constatées sur des pertes d'environ $35^{\circ}$ et des coulées sans cohésion sur des pentes de $30^{\circ}$ et au-dessus. Bien que la plupart des avaianches soient petites, les lignes de rupture superieure dos plaques peuvent atteindre un maximum de longueur de $500 \mathrm{~m}$, et les plaques peuvent avoir jusqu'a $8 \mathrm{~m}$ d'épaisseur. Les premières corrélations entre les déclenchements d'avalanches et les conditions métérologiques ont montré l'importance des périodes froides suivant les fortes chutes de neige et la signification des dégels. Il reste encore beaucoup à faire avant qu'un service de prévision d'avalanches puisse être mis sur pied, le moindre n'étant pas de persuader les éventuels bénéficiaires d'un tel service de l'intérêt qu'il aurait pour eux.

Zusammenfassung. Lawinengefoly in don Caimgorn Motntains, Schottland. Die Lawinenunfalle in Schottland nehmen zu; sie fordern derzeit im Jahresmittel zwei Todesopfer. Die Betroffenen sind entweder Bergsteiger oder Skilangläufer, weil der Gefahr nur an steiteren und abgelegeneren fängen besteht. Studien in den Cairngorm Mountains haben ergeben, dass sich der Schnee in Schottland nach drei Aspekten vom alpinen Schnee unterscheidet: 'Tiefenreif tritt in Schottiand nicht auf; die typischen Dichten und Eindringwerte von Rammsonden lieges höher; Eisschichten komnen häufiger vor. Schneebrettlawinen treten an Hängen mit etwa $95^{\circ}$ Neigung, Rutschungen an solchen mit $30^{\circ}$ und steiler auf. Obwohl die meisten Lawinen klein sind, erreichen die Abrisslinien Längen bis zu $500 \mathrm{~m}$ und Schneebretter können bis zu $8 \mathrm{~m}$ dick sein. Vorläufige Korrelationsrechnungen zwischen Lawinenhäufigkeit und Witterungsverhältrissen weisen auf die Bedeutung kalter Perioden nach heftigem Schneefall und die der Tauperioden hin. Vor Errichtung eines Lawinenwarndienstes muss noch viel getan werden; dazu gehört es auch, die mutmasslichen Nutzniesser einer solchen Einrichtung von deren Wert zu überzeugen.

Scotland has an increasing avalanche problem due to the growing number of people who choose to spend part of their winter ski-ing, climbing, and walking among the mountains. This paper traces the growth of the avalanche hazard in Scotland and describes preliminary steps taken in the Cairngorm area to understand the factors causing avalanche release and the social barriers to the introduction of a forecasting service.

\section{History of the avalanche prodlem in Scotland}

The first recorded avalanche to take place in Scotland was on New Year's Day, r8oo, when a party of five gamehunters was overwhelmed in a shooting lodge in the Gaick hills, just south of the Cairngorms (Table I). The building was completely destroyed (the first and only time in Scotland), and the event was ascribed to supernatural causes (Gordon, 1969). A less well documented avalanche in the shape of a giant snowball fell by the side of a poor man's cottage. Fortunately for both him and his family, when opened it was found to contain 
Table I. Avalanghe accidents in Scotland 1800-1979

$\begin{array}{lcccc}\text { Period } & \begin{array}{c}\text { Number } \\ \text { involving } \\ \text { htmans }\end{array} & \text { Fatalities } & \text { Injured } & \begin{array}{c}\text { Yearly } \\ \text { accident } \\ \text { rate } \\ \mathbf{a}^{-1}\end{array} \\ \text { 1800-1850 } & 1 & 5 & & 0.02 \\ 1851-1900 & 0 & 0 & 0 & 0 \\ 1901-1950 & 14 & 1 & 0 & 0.28 \\ 1951-1958 & 7 & 5 & 7 & 0.83 \\ 1959-1968 & 12 & 4 & 17 & 1.2 \\ 1969-1979 & 42 & 14 & 59 & 3.9 \\ \text { Total } 1800-1979 & 76 & 29 & 85 & 0.42\end{array}$

Based on a survey by Wright (unpublished).

"three brace of ptarmigan, six hares, four brace of grouse, a blackcock, a pheasant, three geese, and two fat stags" (Brown, 1978 , p. 158 ). In Scotland we have good reasons for believing our avalanche problems are unique!

The first reliable reports of avalanches were published just before rgoo in the early volumes of the Scottish Mountaineering Club Journal and the Cairngorm Club Journal. Whilst the latter concentrated on the Cairngorms, the former covered the whole of Scotland, particularly Ben Nevis (Fig. I). Each journal shows a pattern of early interest in avalanches followed by a decline in interest. References to avalanches are rare in the Cairngorm Club fournal after I901, and infrequent in the Scottish Mountaineering Club Journal after 1915. Many of these early articles described minor accidents although, apart from the 1800 disaster, the first injury did not occur until $193^{8}$ and this was no more than a broken ankle.

After 1937 , mountain accident statistics were published annually in the Scottish Mountaineering Club Journal. These were based on newspaper reports and oral accounts, and formed the chief source of avalanche data until 1976 , by which time avalanches accounted for four per cent of all reported accidents (O'Donovan, 1977). This compares with the period 1925-45, during which avalanches accounted for only one accident out of $9^{\circ}$ (Humble, I946). These reports suffer from the drawback of only including those incidents that resulted in a rescue

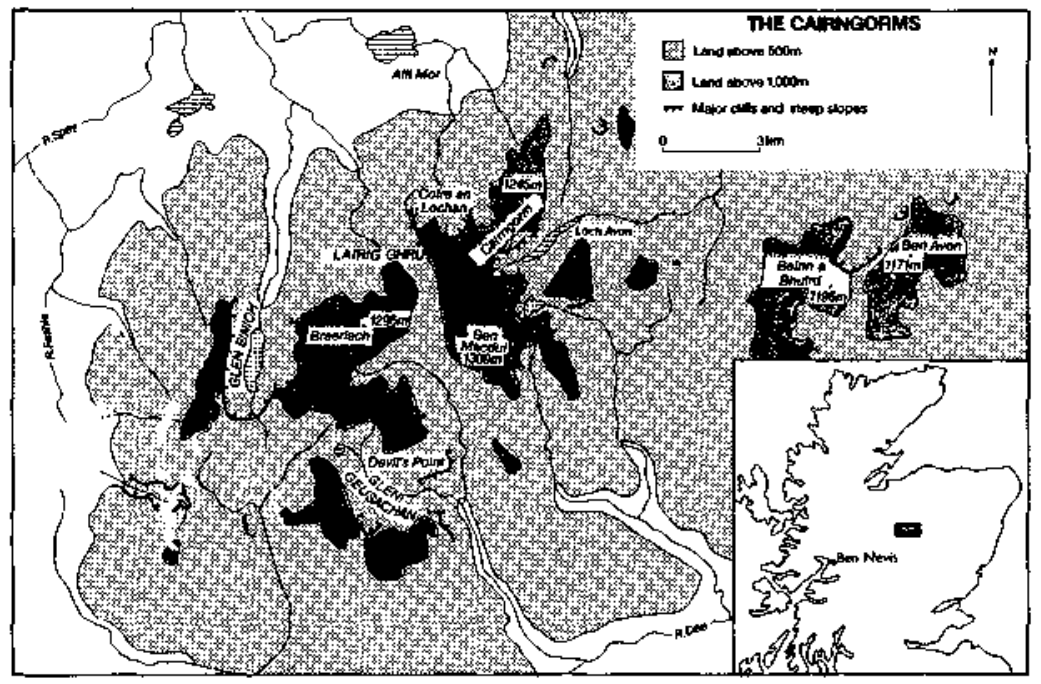

Fig. 1. Lacation map of the Caimgorms. 
team call-out. They therefore exclude all accidents in which the victims were able to free themselves and walk away. As most Scottish avalanches are small, this happens frequently, and in 1978 , for example, walking parties were avalanched without personal damage on five separate occasions. It is a common experience for gully climbers to be bombarded by small avalanches during a winter ascent, and this is expected as "all part of the game".

Field investigations since 1976 have shown that accident reports record only a very tiny percentage of the total number of avalanches in Scotland. Nevertheless that fraction is large enough to have affected over I50 people since 1925 (Wright, unpublished). Since 1970, avalanches have accounted for roughly two fatalities and six injuries per annum. Nearly all these incidents have involved either climbers or hillwalkers, but cross-country skiers have occasionally been caught (Cousins, 1977). The death of climbers is usually caused by the effects of the fall and by striking rocks, but burials affect both climbers and walkers. In 1964, out of four caught, orie avalanche victim survived burial for $22 \mathrm{~h}$, a Scottish record. Hillwalkers are more likely to be injured by large, open-face slab avalanches. Two were killed on 27 December $197^{8}$ by a large avalanche that swept off Braeriach towards Glen Einich.

The problem of avalanche hazard in Scotland is thus different from that in Alpine countries where avalanches damage villages, roads, railways, ski installations, and forested areas, and where the cost of such damage alone justifies research and protection. Only two records exist of an avalanche crossing a road in Scotland, and a train or car has never been hit. There are no communities or single houses at risk and, although on a number of occasions avalanches have damaged Forestry Commission plantations and private woodlands, losses are negligible. Sheep and deer have been killed in avalanches, but such events arouse only Jocal interest. Finally, despite 18 years of operation, the Cairngorm ski installations and pistes have never been avalanched, and there have been only minor accidents on the other main ski area in west Scotland. This situation may change with the planned expansion of ski-ing, but for the time being avalanche danger remains the exclusive problem of the mountaineer and crosscountry skier.

\section{avalanche investrgations in the Gairngorms}

The increase in avalanche incidents, and the inherent interest of Scottish snow itself were the impetus behind the present study which was begun in 1977 . It was designed to analyse the factors responsible for avalanche release and to develop a tentative forecasting model. On the basis that avalanches release when the shearing stresses acting on the snow exceed the frictional forces holding it in place, measurements were made of those variables thought to have a bearing on this balance of forces. Consequently the properties of the snow-pack itself were measured (temperature, density, stratigraphy), as well as those variables that affect the snow-pack, namely weather conditions and topography. Viewed in this way, weather and topography are the independent variables, snow-pack properties are the dependent variables, and avalanche release is the result of a particular configuration of the snow-pack properties in which stress and friction are not balanced. The correlation of avalanche release with weather, topography, and snow-pack parameters depends upon the availability of avalanche records, and these were obtained from fieldwork, climbing journals, books, police records, newspaper euttings, and accident statistics. Letters were sent to all the Scottish climbing clubs asking for information, questionnaires were distributed around campsites, Youth Hostels, and hotels, and advertisements requesting information were placed in some magazines.

The Cairngorm Mountains were chosen as the study area for a number of reasons. First, by virtue of their elevation they retain their snow longer than any other mountain massif in Scotland, with the exception of Ben Nevis. Secondly, owing to the availability of some earlier work (Langmuir, 1969 and unpublished field notes; Beattie, unpublished) a slightly longer span of snow-pit data was obtainable. Thirdly, the area was well served with weather stations. 
Finally, some equipment was available in the area and, due to the ski-ing development, relatively easy access was possible to known avalanche sites by road, chairlift, and on foot.

The Cairngorms comprise a gently undulating plateau with large areas above $\mathrm{I}$ ooo $\mathrm{m}$ and reach a maximum of $1309 \mathrm{~m}$ in Ben Macdui. The plateau surfaces are fringed either by cliffs, typically $5^{\circ}$ to $100 \mathrm{~m}$ high and broken into buttresses divided by numerous gullies, or talus slopes, angled at $35^{\circ}$ with a maximum vertical range of $600 \mathrm{~m}$ in the Lairig Ghru and Glen Einich. Whereas the cliffs form the headwalls of glaciallyscoured corries, the talus slopes bound the main glacial troughs and form arêtes between adjacent corries. There are no trees above $450 \mathrm{~m}$ and heather is the dominant vegetation. Isolated areas of rock slabs occur, as in Goire au Lochan and at the Devils Point.

On average the plateau is $800 \mathrm{~m}$ to $900 \mathrm{~m}$ higher than the surrounding valleys and as a consequence has a different climatic regime. Snow usually lasts all year round in isolated snow-beds, and may fall in every month. Heavy snow-falls of more than one metre are infrequent, but snow may fall in small quantities for several consecutive days. The main period of snow-fall is between November and May, with the coldest temperatures $\left(<-10^{\circ} \mathrm{C}\right)$ occurring in January and February. As the massif is nowhere more than $80 \mathrm{~km}$ from the sea it is frequently affected by warm maritime air bringing in thaw conditions. Temperatures may rise by 10 or $15 \mathrm{deg}$ within a few hours. Cold, clear weather is normally associated with a northerly airstream and warm, cloudy weather with a southerly airflow. Winds are typically between $11 \mathrm{~m} \mathrm{~s}^{-1}$ and $18 \mathrm{~m} \mathrm{~s}^{-\pi}$, reaching a maximum of $68 \mathrm{~m} \mathrm{~s}^{-1}$ in isolated gusts. Days of light variable winds are few.

\section{Snow-pack conditions in the Caimgorms}

During $197^{8}$ and 1979,17 snow-pits were examined and a photographic record of snow distribution in Coire an-t-Sneachda was accumulated when conditions permitted. The main characteristics of the snow-pack were found to be:

(I) The accumulation of large thicknesses of windslab, particularly on lee slopes where snow may lie $30 \mathrm{~m}$ deep (Fig. 2). On 24 January 1978 , poles standing three metres clear of the snow surface on the headwall of Coire Cas were completely buried during a snowfall of $15 \mathrm{~cm}$ accompanied by winds of $20 \mathrm{~m} \mathrm{~s}^{-1}$.

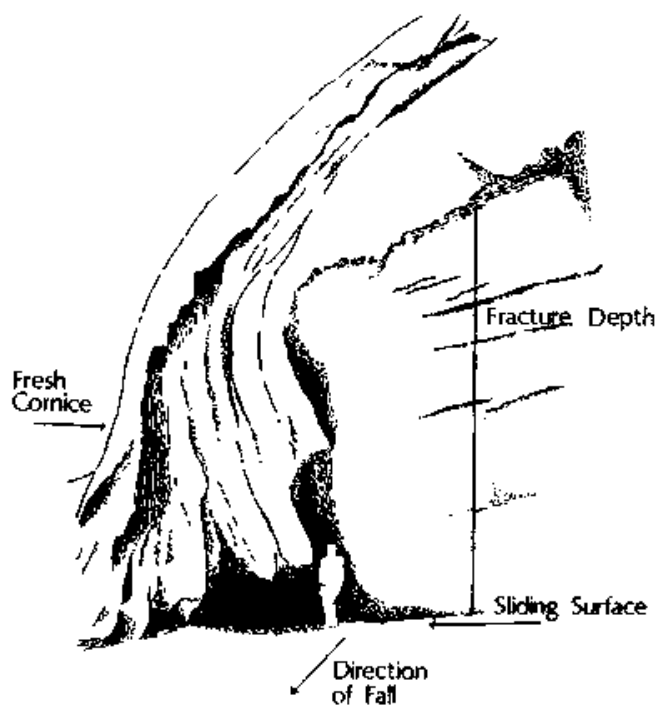

Fig. 2. Large slab-avalanche fracture line with fresh cornice, Lachnagar. Photograph by E. Langmuir. 
(2) Five or six ice layers were commonly found in snow-pit sections (Fig. 3). These reached a maximum thickness of five centimetres, but were usually less than one centimetre. The thinner layers were clear, but thicker layers were often dirty with incorporated soil or twigs. Penetration values of several hundred kilogrammes were measured for the ice layers, which often underlay a slush zone above. The latter resulted from impeded drainage caused by the impermeable ice layers during a thaw.

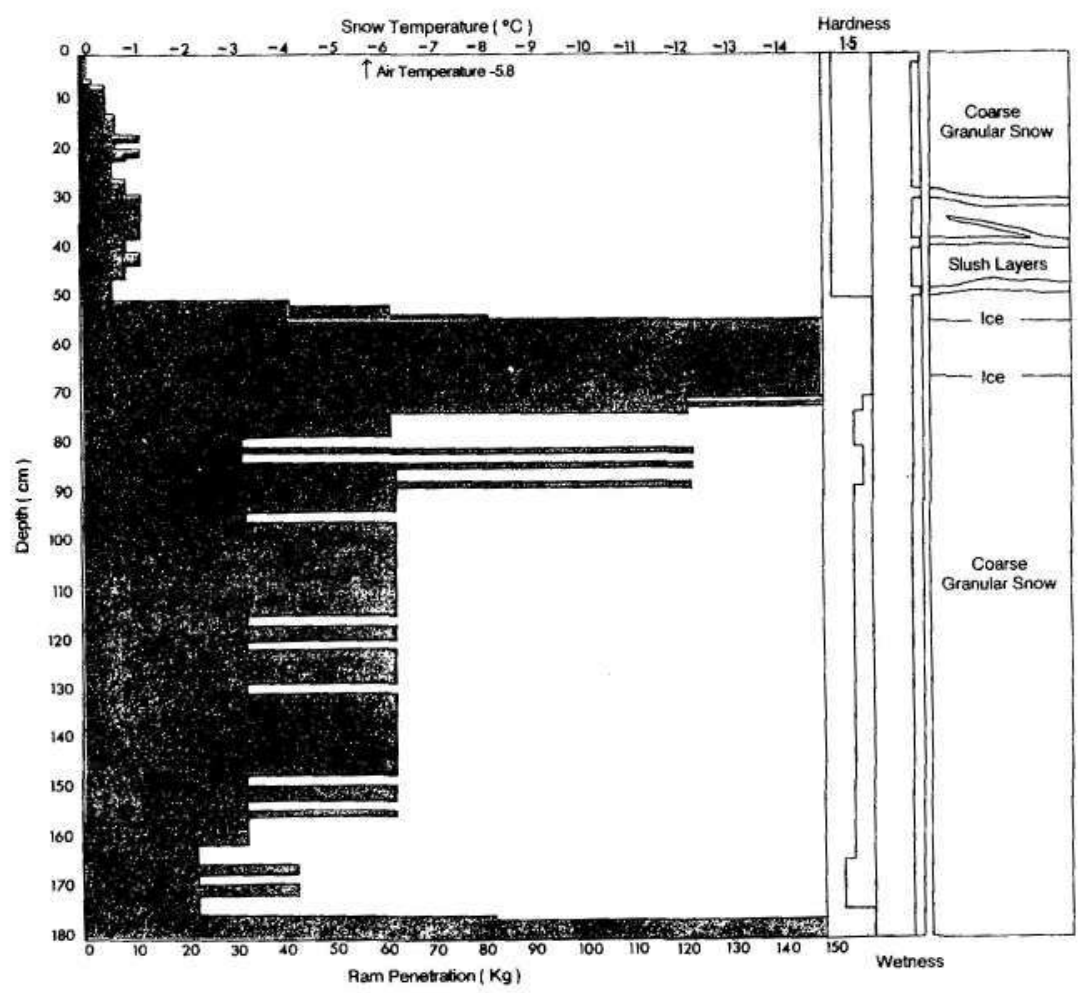

Fig. 3. Snow-pit section at $700 \mathrm{~m}$ on the north of Cairngorm, April 1979. The snow-pack was isothermal.

(3) Coarse granular snow is always found at the base of the snow-pack, and occasionally in the middle or at the top as well. It usually exhibits a variable resistance to penetration, although hard and soft layers may look the same in section and layering may not be visible. In 1978 the lowest levels were always hard, with penetration values of $100 \mathrm{~kg}$ or more. By contrast, a common feature in 1979 was a weaker zone just above the base giving penetration values of $30 \mathrm{~kg}$ or less.

Weaknesses arise in the snow-pack for a number of reasons: Slush layers have been mentioned and these may form at the base of the snow, above rock slabs for example, as well as internally. Another source of weakness is the incorporation of cohesionless grains into the snow. This may happen as a result of fresh snow falling onto a layer of surface hoar following a frost, or due to the inclusion of a layer of hail into the snow during a storm. Hail is common in Scotland, particularly late in the season and, for example, fell on each of the first six days in May 1979. A hail-lubricated avalanche has been reported from the northern Cairngorms (personal communication from R. Barton and B. Beattie, 1976). Beattie (unpublished) has also reported very early depth-hoar formation and Langmuir states that, although practically 
unknown in Scotland "it may occasionally be found in the space created when loose snow settles below a hard slab" (Langmuir, 1969, p. 208-09). However, no evidence of depth hoar was found in 1978 and 1979 , and, as temperatures are never sufficiently low for sufficiently long to permit significant temperature-gradient metamorphism, it is unlikely to be a major cause of avalanches in Scotland. It is, however, fair to say that the absence of depth hoar in 1978-79 may be attributable to the particularly heavy snow-falls that occurred.

Using the snow-pit data from 1978-79, together with results obtained by Beattie (unpublished) as representative of Scottish snow-pack conditions, comparison can be made between Scottish and alpine snow. Work by Keeler (1969), Armstrong and others (1974), and Martinelli (1971) has been taken to be typical of alpine conditions. Three differences emerge:

(i) Depth hoar very probably does not contribute to avalanche formation in Scotland but occurs widely in alpine regions, encouraged by long periods of cold weather.

(2) Average ram penetrometer values are higher in Scotland, and snow densities are higher as well. Individual maximum and minimum values are the same in both areas.

(3) Ice layers appear to be more common in Scotland throughout the wintex.

Warmer temperatures and frequent freeze-thaw cycles in Scotland are responsible for these differences which are most marked in mid-winter, when the alpine snow-pack is most continental, and which disappear towards the alpine spring.

\section{Avalanches: types, location, and frequency}

Altogether about 800 avalanches have been recorded, of which nearly 600 come from $197^{8}$ and 1979. Most of these were seen during two flights on 77 April and 6 May 1979. Avalanches were classified either as wet or dry sluffs or wet or dry slabs. Often the humidity of the snow at the time of release could not be ascertained: in such cases the adjectives wet or dry are omitted. Airborne powder avalanches have not been seen in the Cairngorms although one has been reported from Ben Nevis (personal communication from $\mathrm{H}$. McInnes, 1978). Unless otherwise stated all avalanches are surface avalanches.

\section{(r) Slab avalanches}

Between 28 December 1977 and 31 May 1978, 22 slab avalanches were recorded in the Cairngorms, in Coire an Lochan, Coire an-t-Sneachda, Coire Cas, above Loch Avon, and at other locations on the north side of Cairngorm. Of these, eight were dry-slab avalanches, falling between 27 January and 21 February $197^{8}$, nine were wet, falling between 23 February and $3^{1}$ May $197^{8}$, and five were undifferentiated. Crown fracture lines reached a maximum length of $400 \mathrm{~m}$ and break-off walls were between $30 \mathrm{~cm}$ and $\mathrm{I} \mathrm{m}$ deep.

Between 1 i December 1978 and 6 May 1979 , the remains of 2 I slab avalanches were noted. However, the pattern of avalanching was different, Coire Cas and its neighbouring corries on the east showing no activity, while the local pattern in Coire an-t-Sneachda differed from the previous year. Of these avalanches, six were probably dry and fell between 18 December 1978 and ${ }_{5}$ January 1979 , and seven were wet; the remaining eight were undifferentiated. A fulldepth avalanche on 9 January 1979 , following heavy snow attained a maximum thickness of four metres, and the longest crown fracture line stretched for $500 \mathrm{~m}$ near the head of Glen Einich.

\section{(2) Sluffs}

Sluffs were first recorded on 7 January 1978 and on 11 December 1978 , just prior to the 1979 winter season. On 9 February 1978,14 dry sluffs were seen near Loch Avon as well as one in the Lairig Ghru and two in Coire an Lochan. All other sluffing activity has involved wet snow. In 1979 about 500 wet sluffs were seen throughout the Cairngorms during two air 
flights; on open slopes they often occurred in clusters of four or five, lying side by side like sardines in a tin. A few that issued from gullies were dirty with entrained regolith. On 17 and 19 April 1979, wet sluffs were observed in motion above Loch Avon and in Coire an Lochan. A shallow layer of snow was involved and flow lasted for several minutes at low speed. Both wet and dry sluffs are typically small with a width of only a few metres and run-outs of 50 to $150 \mathrm{~m}$. Where they have been started by a large cornice collapse they may be much larger, building levees (Fig. 4).

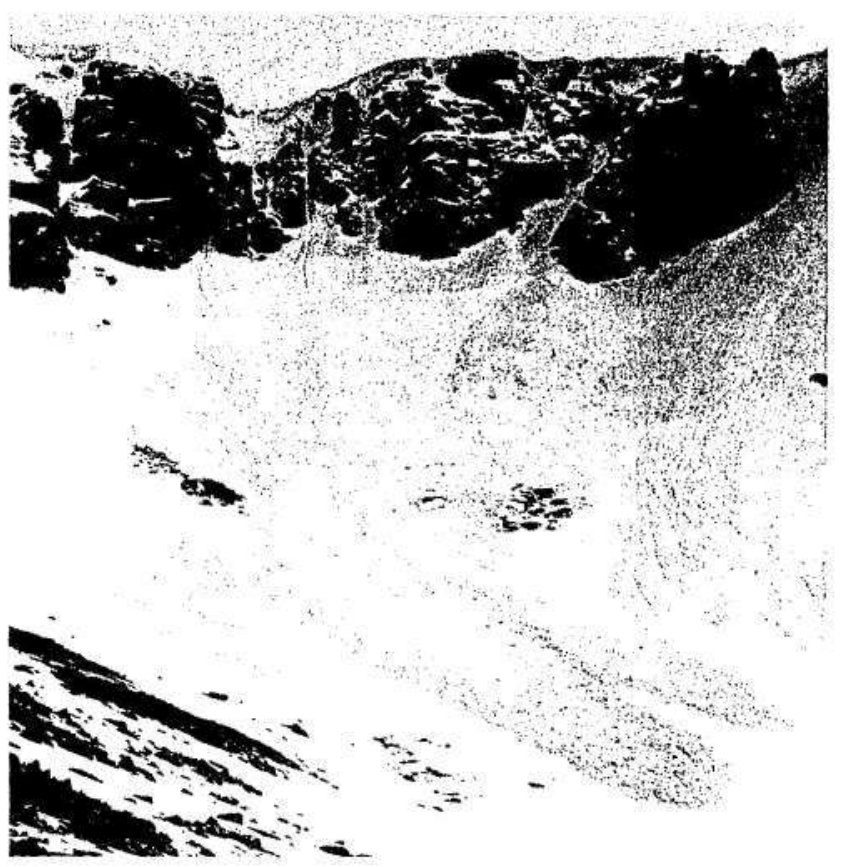

Fig. 4. Wet-snow avalanche and cornice activity in Coire an Lochan, Cairngorm, April 1979.

\section{(3) Cornices}

Due to the strong winds, cornices are a ubiquitous feature of clifftops and some convex ridges. Large cornice falls occur frequently and large blocks were seen in the Allt Mor in February r979. Four cornice collapses were witnessed near Loch Avon from the same crag in half an hour. However, most cornice activity in 1979 involved small parts of the overhanging snow mass, although the cumulative effect of many hundred small falls was the removal of several hundred tons of snow.

A few points should be made in summary. First, although records of wet sluffs far exceed all other avalanche types, this merely reflects the advantage of flying as a means of "avalanche spotting", and not their greater frequency. Dry sluffs are particularly hard to see as they are rapidly covered by loose powder snow drifting over them and many hundreds will fall unseen during blizzards. Accounts of mountain rescues indicate that soft slab avalanches often fall during blizzard conditions and these are not ordinarily seen. Secondly, although most runouts are small and fail to reach level ground, a few examples are known from debris patterns of avalanches crossing valleys and ascending the opposite slope, for example in Glen Geusachan; 
the particular type of motion was not observed. Thirdly, although most slabs are less than one metre thick, blocks of snow six or seven metres thick are commonly reported for the fulldepth avalanches that fall in Coire an Lochan (Walton, 1966; Langmuir, 1969) and Langmuir has described a surface avalanche involving a sliding layer eight metres thick.

\section{Correlation of avalanches with topography and weather}

All the avalanches recorded in $197^{8-79}$ started on slopes with gradients greater than $30^{\circ}$, although in many cases run-outs extended onto much gentler slopes (Fig. 5). Slab avalanches were initiated on slopes of about $35^{\circ}$ and fracture lines occurred either a few metres below the base of cliffs or near the top of talus slopes. Dry and wet sluffs occurred on slopes of all angles above $30^{\circ}$, many of them issuing from gullies.

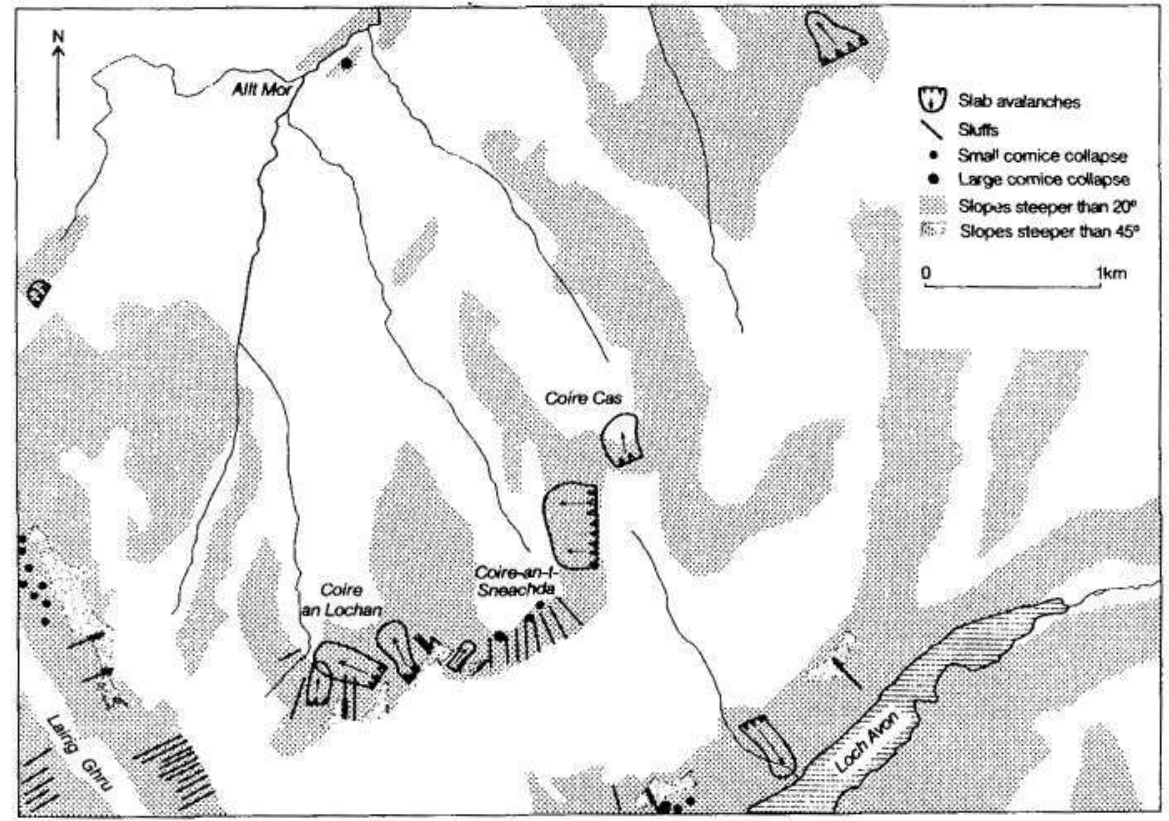

Fig. 5. Relationships between slope angle and type of avalanche activity.

Another important determinant of avalanche location was found to be surface cover and roughness. Slab fractures were seen above smooth rock slabs near Loch Avon and in Coire an Lochan, and a large avalanche falls from the rock slabs near the Devils Point into Glen Geusachan in many years (Scottish Mountaineering Club, I908; Baird and Tranquair, r93 I Smith, 1965). Where the talus is particularly coarse full-depth avalanches have not been seen; for example, on the southern spur of Ben Macdui where boulders and isolated pinnacles stand three or four metres clear of the general surface, both wet and dry sluffs were found to follow the channels of debris flows and were constrained by the levees on either side.

Due to the failure of several experimental and standard high-level automatic weather stations, only tentative conclusions may be drawn concerning the relationships between prevailing weather and avalanche release. Furthermore, the avalanche data were recorded only when the remains were seen, which may differ from the release date by several days. This is especially true of 1979 and the period between 31 January and 9 February 1978 . The main associations are: 
(1) Between 28 January and 4 February 1978, a deep depression to the south-west gave rise to very strong winds $\left(27 \mathrm{~m} \mathrm{~s}^{-1}\right.$ to $3^{2} \mathrm{~m} \mathrm{~s}^{-1}$, gusting to $\left.45 \mathrm{~m} \mathrm{~s}^{-1}\right)$ from the northeast, accompanied by an exceptionally heavy snow-fall of about three metres. It is likely that intense dry slab and dry-slab activity characterized this period, although the hills were unapproachable until 9 February, when a few dry sluffs were seen. Perla and Martinelli (1976, p. 35) state "It is an observed fact that the vast majority of avalanches release during or after storm periods".

(2) Between 8 February and 21 February 1978 , very cold temperatures prevailed (minimum recorded, $-20^{\circ} \mathrm{C}$ in the Spey valley), and avalanches fell between 19 and 21 February. These were large dry-slab avalanches.

(3) Between 22 and 24 February freezing level rose by $2000 \mathrm{~m}$ and wet slab avalanches fell on 23 and 24 February. Wet sluffs fell between 23 February and 1o March, and wet slab avalanches fell infrequently between 3 March and the end of May.

(4) In 1979 there was no big snow-fall as in the previous year and predominantly warm weather persisted from the middle of February. Snowy, warm weather lasted from 28 February until 9 April and a "thaw cycle" emerged after the latter date. In general terms the cycle had three phases:

(i) Small partial collapses of cornice occur. No entrainment of snow from lower down takes place.

(ii) Sluffs begin to form as cornice falls entrain snow from the lower slopes. Probably some wet slab avalanches fell at this time.

(iii) Spontaneous initiation of sluffs begins and full-depth fracture lines appear above rock slabs.

Throughout this period there was large-scale movement of free water giving the snow a stained appearance throughout the hills.

The most significant factors governing avalanche release in 1978 and 1979 appeared to be the period of cold weather immediately following the heavy snow-fall in 1978 , thus inhibiting the consolidation of the snow mass, and the extent of thawing in 1979 which permitted the development of several slush layers and which promoted extensive drainage of free water through the snow and along ice layers.

\section{TOWARdS AYALANGHE PORECASTING}

Avalanche forecasting has both scientific and human aspects. Existing scientific data are very limited and suffer from spatial and temporal biases. The above results, from 1978 and 5979, were obtained during unusually snowy winters and therefore may not constitute a peliable sample from which to draw general conclusions. Furthermore, the differences between Scottish and alpine snow suggest that forecasting techniques developed in alpine areas may require some modification before they can be applied successfully in Scotland. However, since work began in the Cairngorms, particularly hazardous slopes have been identified and general relationships between weather conditions and avalanche release are emerging. More research is now required to build upon these preliminary results.

It is here that social factors become important. Due to a lack of interest and financial upport, a previous suggestion to provide a scientific avalanche-forecasting service as part of the Countryside Commission's "Speyside Project" was rejected (personal communication from J. Porter, 1979). The lack of support was based on the view that the effort involved was not justified by the likely benefit, which, as has already been established, would only be enjoyed by mountaineers and the occasional cross-country skier. Response towards proposed forecasting services was, and still is, mainly negative. 
The antipathy of mountaineers towards avalanche forecasting does not extend to research in general. Specific answers to specific questions, such as the rate at which cornices weaken and strengtheil during melt-freeze cycles, would be welcomed (personal communication from W. R. Brooker, 1979), but there are two reasons why forecasting would not. The first is that existing forecasts, issued by the Inverness Constabulary and on the basis of informed local opinion, do more harm than good. They are blanket warnings and once given are rarely retracted. A notice stating "Avalanche Danger-Acute" was displayed at the Forestry Commission Information Centre continuously for two months between March and May 1979. Although correct in general terms, for avalanches occurred throughout the Cairngorms over the duration of the notice, obviously for most of the time individual slopes and gullies were quite safe. Such notices acquire a "crying-wolf" character, as supposedly unstable slopes can be safely negotiated, with the result that accurate forecasts may be ignored.

The second problem is more personal and derives from the motives that cause people to climb or ski the remoter slopes. One of these motives is the freedom to go where one chooses, without being answerable to some authority, and the other motive is to expose oneself to a degree of risk. How big a risk depends upon the individual's character and experience, but the right to take risks is a basic mountaineering ethic, and the existence of a risk essential to the enjoyment of the sport. The fear that a large-scale research project may violate these essentials has been clearly expressed by the vice-principal of Scotland's foremost Outdoor Sports Centre:

"Should there then be finance and scholars urged on to the hills with a remit to report on their custody of the snows? Should our beloved National, Regional, Local or Tribal Big Brothers take it upon themselves to make the mountains safe for us all yet again? Doubt* less, someone, someday, will argue for it. May it be suggested that this, like all such official lay lunacies regarding mountain accidents, hazards, the people, and their fun, is damn nuisance and futile for the Scottish Situation" (O'Donovan, 1977, P. 135).

Perhaps a more typical reaction to proposals for avalanche forecasting is that expressed by a local mountain-rescue team leader: "Mountaineers are molly-coddled enough!" Though less violently opposed to avalanche forecasting than $O^{\prime}$ Donovan's view, it is no more favourable. For the present avalanche research remains low-key, but initiatives taken at the Outdoor Sports Centre have resulted in two national avalanche seminars attended by police, mountain-rescue team leaders, and other interested parties. Until useful avalanche forecasting becomes a reality this approach should curb the increase in avalanche accidents by helping hill-users to make their own judgements in an informed way.

\section{ACKNOWLEDGEMENTS}

I would like to thank all those who volunteered their help in this project, particularly Jo Porter, Eric Langmuir, the late Ben Beattie, and Fred Harper and his staff, as well as many members of the Scottish Mountaineering Club, the Mountain Rescue Committee of Scotland, and other Scottish climbing clubs. David Sugden made helpful suggestions to improve the manuscript. I am very grateful to the Natural Environment Research Council for a studentship to carry out this research.

\section{REFERENCES}

Armstrong, R. L., and others. 1974. Development of methodology for evaluation and prediction of avalanche hazard in the San Juan Mountain area of southwestern Colorado, [by] R. L. Armstrong, E. R. LaChapelle, M. J. Bovis, J. D. Ives. Unitersity of Colorodo. Institute of Arctic and Alpine Research. Occastonal Paper No. I3.

Baird, P. D., and Tranquair, R. N. 1931. A week at Corrour Bothy. Scottish Mountaineoring Club Journal, Vol. 19, No. I I2, p. $252-56$. 
Beattie, B. Unpublished. The densification of a seasonal snowpack in the Cairngorms with relation to avalanches. [B.S. thesis, University of Lancaster, 1976.]

Brown, H. 1978. Hamish's mounlain walk. London, Victor Gollancz Ltd.

Cousins, A. 1977. Avalanched! Scottish Mountaineering Club Journal, Vol. 31, No. 168, p. 130-33.

Gordon, S. 1949. Highways and byways in the central Highlands. London, Macmillan and Co. Ltd.

Humble, B. 1946. A survey of mountain accidents in Scotland, 1925-45. Scottish Mountaineering Club Journal, Vol. 23, No. 137, p. $325-32$.

Keeler, C. M. Ig69. Some physical properties of alpine snow. U.S. Cold Regions Research and Engineering Laboratory. Research Report $27 \mathrm{I}$.

Langmuir, E. D. G. Ig69. Mountain leadership. Official handbook of the Mountain Leadership Training Boards of Great Britain and Northern Irelard. Edinburgh, Scottish Sports Council.

Martinelli, M., ir. 197 r. Physical properties of alpine snow as related to weather and avalanche conditions. U.S. Dept. of Agriculture. Forest Service. Research Paper RMn 64 .

O'Donovan, R. 1977. Snaw Ba's. Scottish Mountaineering Club Journal, Vol, 31 , No. 168 , p. 133-37.

Perla, R. L., and Martinelli, M., jr. 1976 . Avalanche handbook. U.S. Dept. of Agricullure. Forest Service. Agriculture Hondbook $4^{89}$.

Bootish Mountaineering Club. Iga8. Proceedings of the Club. Scottish Mountaineering Club Journal, Vol. 10, No. 57 , p. 150 .

Smith, M. 1965 . Climbers guide to the Caimgorms area. Vol. I (northern district), the Cairngarms. Edinburgh, Scottish Mountaineering Club.

Walton, S. 1966 . Glenmore Caimgorms: Forest Park guide. Edinburgh, H.M.S.O.

Wright, B. Unpublished. Avalanche accidents in Scotland. [Lecture presented at National Avalanche Seminar, Glenmore Lodge, 1979.] 